\title{
Two remarkable pinworms (Nematoda: Enterobiinae) parasitizing orangutan (Pongo abelii) in the Sumatra (Indonesia) including Lemuricola (Protenterobius) pongoi n.sp.
}

\author{
I. FOITOVÁ ${ }^{1}$, V. BARUŠ ${ }^{2}$, I. HODOVÁ ${ }^{1}$, B. KOUBKOVÁ ${ }^{1}$, W. NURCAHYO ${ }^{3}$
}

\begin{abstract}
${ }^{1}$ Department of Botany and Zoology, Faculty of Science, Masaryk University, Kotlářská 2, 61137 Brno, Czech Republic, E-mail: foitova@sci.muni.cz; ${ }^{2}$ Department of Zoology and Fisheries, Faculty of Agrobiology, Food and Natural Resources, Czech University of Life Sciences in Prague, Kamýcká 957, 16521 Prague 6 - Suchdol, Czech Republic; ${ }^{3}$ Department of Parasitology, Kedokteran Hewan Faculty, Gadjah Mada University, Yogyakarta, Indonesia
\end{abstract}

\begin{abstract}
Summary
Two species of pinworms (Enterobiinae) were collected from fresh faeces of semi-wild orangutans Pongo abelii Lesson living in northern Sumatra (Indonesia). The female of Enterobius (Enterobius) buckleyi Sandosham, 1950 is redescribed. Lemuricola (Protenterobius) pongoi n. sp. is described on the basis of females (no males are available) and distinguished from L. (P.) nycticebi (Baylis, 1928) by cephalic and mouth morphology (head and teeth superstructures), body $(9.85-15.46 \mathrm{~mm})$ and tail $(2.34-2.95$ $\mathrm{mm})$ length, smaller eggs (48 - 56 x $22-28 \mu \mathrm{m})$, longer vulva distance from anterior extremity $(2.05-3.09 \mathrm{~mm})$ and other features. Characteristic is the total body length/oesophagus length ratio (1 : 15.3 - 22.0). Both nematode species were studied using scanning electron microscopy for the first time.
\end{abstract}

Key words: Orangutan, Oxyuridae, Sumatra, Lemuricola (Protenterobius) pongoi n.sp., Enterobius (Enterobius) buckleyi

\section{Introduction}

For critically endangered great apes of the genus Pongo Lacépède (Hominidae: Ponginae) data on occurrence of their parasites are patchy and mainly limited to captive animals. The first field-based study of parasites in wild orangutan populations were presented in the unpublished PhD thesis by Rijksen (1978) and Foitová (2002). There is only one study published on the parasites of wild, captive and newly reintroduced orangutans in Indonesia (Kalimantan and Sumatra) by Collet et al. (1986), and Mul et al. (2007).

In hosts of the order Primates, pinworm subfamily Enterobiinae Hugot, Gardner et Morand, 1996 is very interesting for the systematic and cospeciation point of view (Hugot et al. 1996, Hugot 1999). Four species have been reported from orangutans: Enterobius buckleyi Sandosham, 1950, E. foecundus (Linstow, 1879), E. simiae MacCallum, 1921 and Pongobius hugoti Baruš, Foitová, Koubková, Hodová, Šimková et Nurcahyo, 2007 (see Baruš et al., 2007). In the present study, descriptions of two species of pinworms (based on females) parasitizing the native Sumatran orangutan Pongo abelii Lesson are provided, including scanning electron microscopy data.

\section{Materials and methods}

The locality of investigation, the village Bukit Lawang (former home to a rehabilitation centre for orangutans) is situated on the southwestern border of the Gunung Leuser National Park (northern Sumatra, Indonesia) (0332.983' $\mathrm{N}, 098^{\circ} 06.908^{\prime} \mathrm{E}$ ) at an altitude of $323 \mathrm{~m}$ above sea level. Temperatures range between $21^{\circ} \mathrm{C}$ and $28{ }^{\circ} \mathrm{C}$ and relative humidity between $80 \%$ and $100 \%$. Annual rainfall is 2000 $-3200 \mathrm{~mm}$. The majority of orangutans in this area live in a semi-wild population. From the fresh faeces of three adult female orangutans, 12 worms were collected in 2002 and immediately fixed in $70 \%$ ethanol. These nematodes were cleared in glycerine (mixture 1:1 with $70 \%$ ethanol) and examined under a light microscope equipped with differential interference contrast (DIC), digital image analysis system (analySIS FIVE DOCU) and a drawing attachment was used for morphometric analysis.

Parasite specimens used for scanning electron microscopy (SEM) were washed several times in $0.6 \%$ saline, fixed with hot $4 \%$ formaldehyde solution and stored at room temperature. Prior to examination, the parasites were subsequently dehydrated through ethanol, dried in a CPD 030 critical point drying apparatus (Bal-tec) using liguid $\mathrm{CO}_{2}$, mounted on aluminium stubs with double sided adhesive disc, coated with gold in a SCD 040 sputter coating unit (Balzers) and examined in a VEGA (Tescan) scanning electron microscope operating at $20 \mathrm{kV}$. 


\section{Results}

Oxyuridae Cobbold, 1864

1. Enterobius (Enterobius) buckleyi Sandosham, 1950 (Figs. 1, 2)

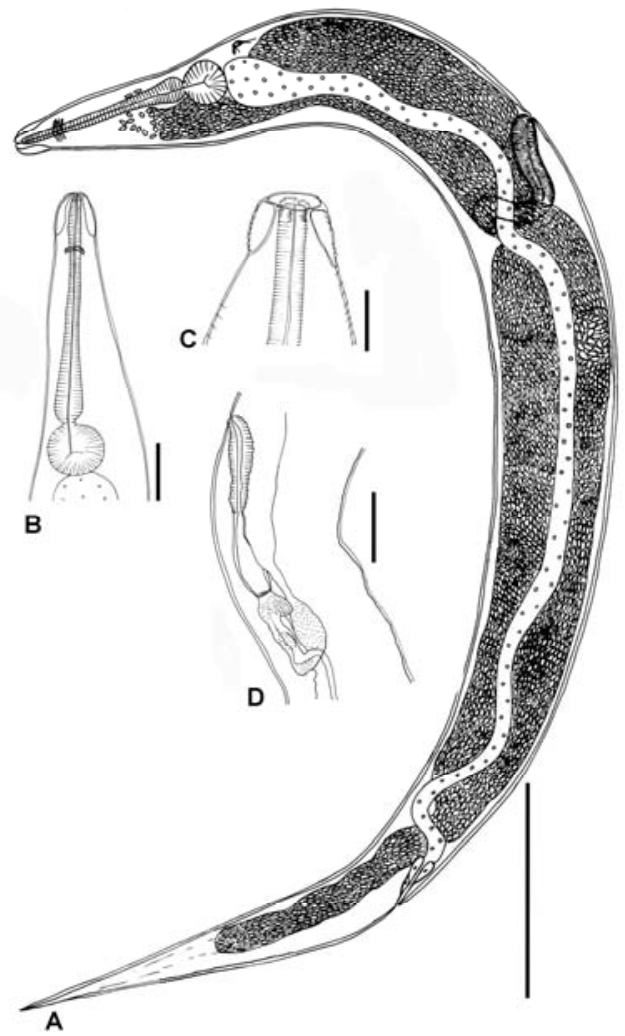

Fig. 1. Enterobius (E.) buckleyi, female. A - total view; B - anterior extremity; C - cephalic region; D - vulva region, lateral view. Scale bars: $A=1000 \mu \mathrm{m} ; \mathrm{B}, \mathrm{D}=200 \mu \mathrm{m} ; \mathrm{C}=100 \mu \mathrm{m}$.

\section{Description}

Female (based on 6 ovigerous specimens; measurements of one juvenile nonovigerous specimen in parentheses): Medium sized, whitish nematodes. Cuticle with clear transverse striations, cephalic vesicle present and well developed, with transverse striations. Lateral alae in cervical part consisting of single crest, and posterior part with double crests. Mouth triangular, surrounded by three obtuse lips; in mouth cavity, dental apparatus present, corresponding to respective lips, and consist of three wide and obtuse teeth opposed to lips. Dorsal lip is wider, with two hemispherical papillae; two subventral lips each with two cephalic papillae, one dome-shaped, one incorporating amphid. Oesophagus with short pharyngeal part, corpus slightly enlarged and continuing in very short isthmus, bulb rounded with valvular apparatus. Excretory pore situated at bulbal or slightly postbulbal level. Vulva preequatorial, muscular vagina and uterine tube divided into two parts by cellular wall forming diaphragm; no spermatheca observed. Length of body: ovigerous specimens $7.35-9.35 \mathrm{~mm}$ (range), juvenile specimen (measurements in parentheses) $5.35 \mathrm{~mm}$, maximum width $572-806$ (386) $\mu \mathrm{m}$; width at bulb $393-691$ (381), at vulva $565-791$
(361), at anus 266 - 536 (183); cephalic vesicle length 129 - 193 (118), cephalic vesicle width 150 - 190 (128). Total oesophagus length $1026-1169$ (1089); pharynx length 62 - 93 (65); width 40 - 52 (34); corpus length 737 - 901 (890), corpus width $70-124$ (87); isthmus length $14-41$ (17), width 31 - 47 (39); bulb length 169 - 217 (169), width 164 - 235 (143). Nerve ring 230 - 320 (260); excretory pore 858 - 1374 (1046); vulva 1668 - 2394 (1710) from anterior extremity. Oviduct directed posteriorly, muscular vagina length $314-526$ (433); vagina width $97-141$ (50). Amphidelphic. Distance vulva to anus 3764 - 5261 (1363); tail long, conical, with pointed apex, $182-2344$ (1280). Eggs numerous, ellipsoidal, with flattened side, 50 - 55 long, and 23 - 27 wide, having three longitudinal thickenings.

Ratios: Total body length/total oesophagus length 6.83 8.95, (4.12); total body length/tail length $3.69-4.91$, (4.18); total body length/vulva distance from anterior extremity $3.40-4.40,(3.13)$; vulva - anus distance/tail length $1.72-2.76,(1.07)$.

Host: Pongo abelii Lesson, 1827 (Primates: Hominidae). Locality: Northern Sumatra, Bukit Lawang (0332.983' N, $\left.098^{\circ} 06.908^{\prime} \mathrm{E}\right)$

Site of infection: discharged in faeces

Material: Voucher specimens $(n=6)$ from 3 orangutans in the helminthological collection of the Research Centre for Biology LIPI, Zoology Division, Puslit Biology LIPI, Cibinong, Indonesia (Cat. No. MZBNa 412).

Remarks

Sandosham (1950) noted that material for description of $E$. buckleyi consisted of three males and 8 females obtained from the appendix of Bornean orangutan Pongo pygmaeus (Linnaeus), which died in the laboratory of Professor Buckley in London. Borneo was designated in the original description as the type locality (= terra typica). Our finding is the second report of this pinworm species, and the first from native territory and new host (Sumatra, $P$. abelii).

The morphology of the worms (females) in our material is generally the same as that described by Sandosham (1950). In the head morphology the species is clearly consubgeneric with members of the subgenus Enterobius (Enterobius) Leach, 1853 as is evidenced by its SEM study, and from a comparison with the type species of the genus (E. vermicularis Linnaeus, 1758), studied by Tenora et al. (1981).

Identical features of subgeneric weight were found in form of lips, numbers and distribution of cephalic papillae on lips, presence of three teeth with rounded margins in the mouth cavity, and the form of female genital characteristics of the genus Enterobius (see Hugot et al., 1996; Fig. 4A, pp. 154 - 155). Small difference was found in the excretion pore location. According to Sandosham (1950) "is at the level of the posterior bulb of the eosophagus". In our material $(n=7)$ is situated at the bulb level $(n=3)$, or slightly postbulbal, at distance $86-280$ postbulbal (mean 174) $(n=4)$. We consider these character as intraspecies variability. The measured features in our material reflected 

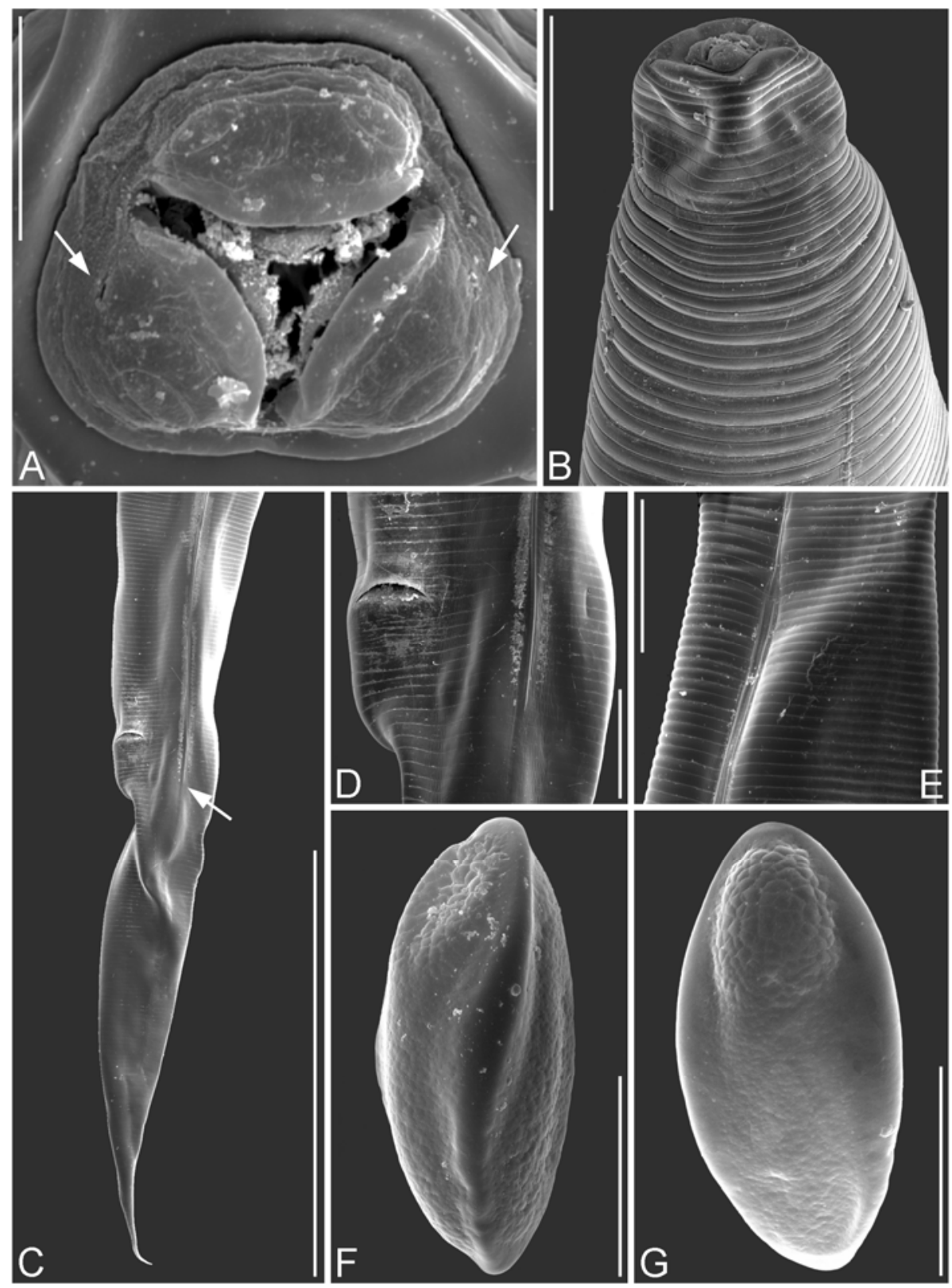

Fig. 2. Enterobius buckleyi female; scanning electron micrographs. A - cephalic end, papilae, teeth (apical view, arrows - amphids); B - forebody, dorsolateral view; C - tail end, lateral view, arrow - end of lateral ala; D - detail of anus, ventrolateral view; E - detail of lateral ala, transition from single to double crest; F - egg, total view; G - egg, egg pole with granular structure, total view; Scale bars: $A, F, G=20 \mu \mathrm{m} ; \mathrm{B}, \mathrm{D}=100 \mu \mathrm{m} ; \mathrm{E}=200 \mu \mathrm{m} ; \mathrm{C}=1 \mathrm{~mm}$.

a higher variability in relation to the pinworm specimens' body length. Females studied by Sandosham (1950) attain body length $6.96-7.25 \mathrm{~mm}$ and their body is shorter at $386-2.096 \mathrm{~mm}$ than ovigerous specimens in our material. Nonovigerous female (length $5.353 \mathrm{~mm}$ ) is shorter of $1.600 \mathrm{~mm}$ in comparison with minimum length in original description. Our specimen has maximum body width of 16 $\mu \mathrm{m}$ higher than reported by Sandosham (1950) $(370-420$ $\mu \mathrm{m})$. This difference doesn't have any taxonomic significance and it's probably results of compression during sample preparation; in females without eggs in uterus is very common. Body length affect oesophagus length less distinctly, which in comparison with original description (0.9
$-0.99 \mathrm{~mm}$ lenght) in our studied specimens is longer of $126-179 \mu \mathrm{m}$; transparently affect tail lenght, which is longer of $474-864 \mu \mathrm{m}$ (in Sadosham description-1.350 $1.480 \mathrm{~mm}$ ). From ratios value we remark the difference in values $\mathrm{R}=$ prevulval body length/postbulbal body length. According to Sandosham (1950) the range is $1.7-1.78$ (females $6.96-7.25$ of the body length). Adult females in our material cover ratio range $2.39-3.40$; in the juvenile specimen (body length 5.353) is ratio 1.55 only. Ratio value rises on body grow. Small oesophagus length difference is considered as result of intraspecies variability. Our measurements of eggs present the variability range (50 55 x 23 -27); Sandosham (1950) states only one measure 
(56 x 26). Differences described in the egg structure (three longitudinal thickenings present) and presence of a subpolar lid noted in our material result from a more detailed SEM study of our material.

Pinworm parasites of the great apes and man (Hominidae: genera Gorilla Geoffroy, Pan Oken, Homo Linnaeus and Pongo Lacépède manifested under cladistic analysis of the Enterobiinae by Hugot (1999) support the Cameron's hypothesis in its assertion of "association by descent" (Cameron 1929). In the apes and humans group, the Enterobius contain four host-specialised species: E. lerouxi Sandosham, 1950 in Gorilla gorilla (Savage et Wyman); E. anthropopitheci (Gedoelst, 1916) in Pan paniscus Schwartz and P. troglodytes Blumenbach; E. buckleyi Sandosham, 1950 in P. pygmaeus and P. abelii; and E. vermicularis in Homo sapiens Linnaeus. Nakano et al. (2006) documented that the synonymy of E. gregorii Hugot, 1983 with E. vermicularis was supported by the molecular evidence. All these pinworm species are well described or recently redescribed (Skrjabin et al. 1960; Hugot and Tourte-Schaeffer 1985, Hugot 1993; Hasegawa et al. 2005) and are clearly different.

Two other species of Enterobius have been described from the orangutan ( $P$. pygmaeus) kept in captivity ( $\mathrm{ZOO})$; namely E. foecundus (Linstow, 1879) and E. simiae (MacCallum, 1921). Cameron (1929) did not provide any different or additional data on these two species in his review of Enterobius in Primates. He expressed the opinion that $E$. simiae is possibly identical with E. foecundus. The description by McCallum (1921) is very inadequate compared to current standards, containing only data on the body length $(6.00 \mathrm{~mm})$ and width $(0.30)$, statement that "the vagina is at about the beginning of the posterior third of the worm" and "both sexes are much alike in appearance". His illustrations of the anterior and posterior ends of the female without any accompanying scale add little information of taxonomic value to the verbal description.

In the original description of E. foecundus (syn. Oxyuris foecunda) by Linstow (1879), the mouth shows two small rounded lips, and no lateral alae. Body length of the female is $6.5 \mathrm{~mm}$ and width $0.66 \mathrm{~mm}$. The oesophagus in the female is $1 / 6.4(=1.015 \mathrm{~mm})$ of the total body length and tail $1 / 6(=1.083 \mathrm{~mm})$ of the body length; eggs measures $56 \mathrm{x}$ $26 \mu \mathrm{m}$ and have a smooth shell. The females of E. buckleyi in our material differ in all above-mentioned features and mainly by a longer tail. In comparison with Sandosham (1950) description, males differ in the spicule length $(0.1225$ vs. $0.052 \mathrm{~mm})$. For this reason, E. foecundus is not considered conspecific with E. buckleyi, but we support the opinion of Inglis (1961) "that E. simiae was rightly treated by Sandosham (1950) as nomen inquirendum, it is better to treat it and probably E. foecundus also, as nomina dubia".

\section{Lemuricola (Protenterobius) pongoi n.sp. (Figs. 3, 4)}

Description

Female (holotype; and 5 paratypes): Small worm, whitish coloured, tapering to both extremities; body (holotype) 15.46; paratypes (range and mean) $9.85-12.11,11.57 \mathrm{~mm}$ length and $880 ; 700-801,755 \mathrm{~mm}$ maximum width. Width at bulb 594; $404-505,474$, at vulva 826; 693 808,752 , at anus $400 ; 308-430,379$. Cuticle with clear transverse striations on cephalic vesicle and body. Lateral alae developed, originating slightly posterior to vesicular end, in cervical part consisting of single crest, and posterior part with two parallel crests, terminating slightly posterior to anus. Mouth triangular, rounded by three small lips (wider than higher) and leading into shallow bucal cavity. Dorsal lip with two hemispherical papillae, two subventral lips bears a hemispherical papilla near ventral rim, and other papilla near lateral rim of lips, with amphid conspicuous opening. Mouth cavity armed with three tooth structures arising from each sector of oesophagus. Wide, leaf-like and flat tooth to the inner wall of each lip adjoing and slightly overlaps top margin of the lips. Inner tooth width is $1 / 3$ of width of corresponding tooth. Inner tooth element protrude from the bottom of prostom funnel to the mouth cavity (having common base with external tooth). Inner teeth are short, triangular and flat with top oriented medially. Tip is armed by $5-6$ very small teeth like spurs. Cephalic vesicle 125; 110 - 146, 127 length, and 204; 159 - 191, 179 maximum width. Total oesophagus length 703; $625-709,676$, pharynx length $71 ; 35-89,69$ and width $56 ; 44-58,51$; corpus length 422; 255 - 398, 339 and width $69 ; 58-108,74$. Short isthmus present, 75; $34-51$,

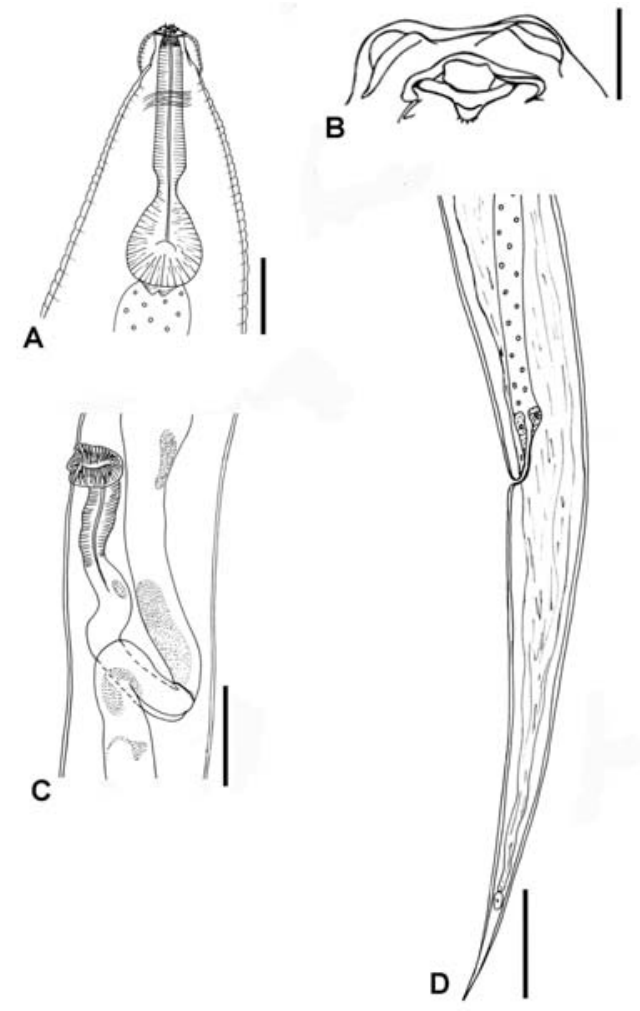

Fig. 3. Lemuricola (P.) pongoi n.sp., female. A - anterior extremity; B - detail of mouth opening - dorsal lip with two hemispherical papillae, the tip of inner tooth with very small tooth like spur; C vulva region - lateral view; D - tail end - ventrolateral view; Scale bars: $\mathrm{A}=100 \mu \mathrm{m} ; \mathrm{B}=10 \mu \mathrm{m} ; \mathrm{C}, \mathrm{D}=500 \mu \mathrm{m}$. 

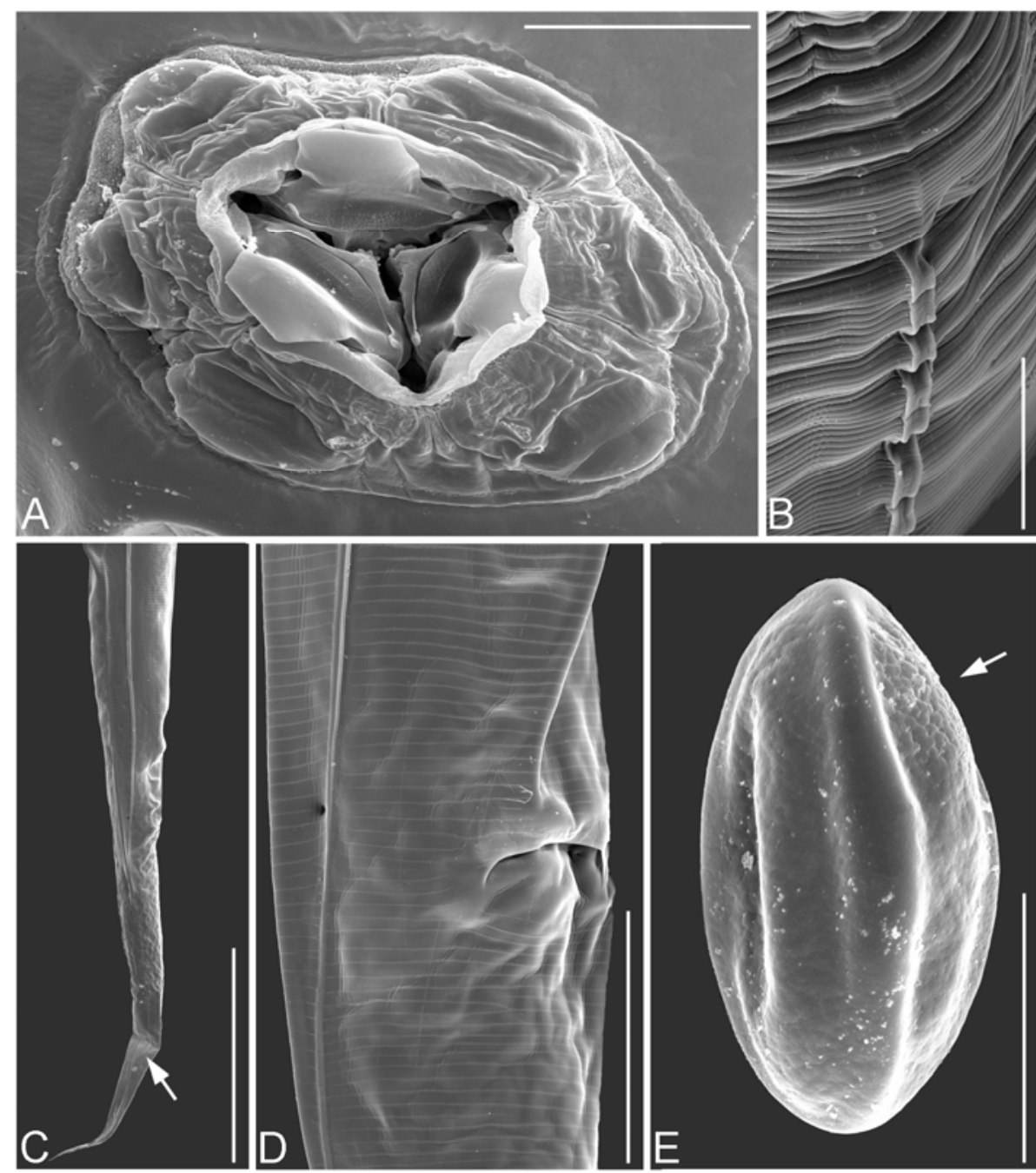

Fig. 4. Lemuricola (P.) pongoi n.sp., female; scanning electron micrographs. A - cephalic end (apical view), cephalic papillae and teeth with superstructures; B - lateral ala, forepart of body; C - tail end of female, lateral view, arrow - end of lateral ala; D - detail of anus, ventrolateral view; $\mathrm{E}$ - egg, total view, arrow - subpolar plug with granular structure; Scale bars: A, E=20 $\mu \mathrm{m} ; \mathrm{B}=100 \mu \mathrm{m} ; \mathrm{D}=200 \mu \mathrm{m} ; \mathrm{C}=1 \mathrm{~mm}$.

47 length, and $39 ; 32-71,43$ width, containing valve in piriform bulb, 246; 222 - 264, 247 length, and 205; 156 243, 196 width. Nerve ring 243; $156-226,196$, excretory pore 1126 ; 653 - 1037, 869, vulva 3093; 2046 - 2936; 2488, from anterior extremity. In females longer than 10 $\mathrm{mm}(\mathrm{n}=5)$ the vulva closed by dark brown cement. Ovijector directed posteriorly; vagina muscular, 881; 543 956, 722 length, and 123; 81 - 139, 117 in maximum width. Vagina uterina divided into two portions by thick cellular wall (diaphragm). Distance between vulva and diaphragm longer than that between diaphragm and uterine opening. Amphidelphic. Distance of vulva to anus 9413; $5092-6729,6338$. Tail conical with pointed apex, 2951; 2339 - 2786, 2610 long. Eggs $(n=25)$ ellipsoidal, with flattened side, 48 - 56; 53.4 long and 22 - 28, 24.8 wide; having three longitudinal thickenings, the lid is subterminal, has a coarsely granulated texture, an irregular elliptic form.

Ratios: Total body length/total oesophagus length 21.98;
$15.3-19.0,17.1$; total body length/tail length $5.24 ; 3.6-$ $5.2 ; 4.4$; total body length/vulva-head distance $4.99 ; 3.6$ 5.0; 4.7; vulva-anus distance/tail length $3.2 ; 1.8-2.7 ; 2.44$.

Type host: Pongo abelii Lesson, 1827 (Primates: Hominidae).

Type locality: Northern Sumatra, Bukit Lawang (0332.983' N, 098 06.908' E)

Site of infection: discharged in faeces

Number of specimens studied: measured, 6 adult females and 1 juvenile female; SEM studied by 1 female.

Type material: Holotype and four paratypes deposited in the helminthological collection of the Research Centre for Biology LIPI, Zoology Division, Puslit Biology LIPI, Cibinong, Indonesia (Cat. No. MZBNa 411).

\section{Discussion}

Although the male was not found, the present species is assigned to the genus Lemuricola subgenus Protenterobius 
Inglis, 1961 (Enterobiinae) which has a mouth opening surrounded by three non-prominent lips (wider than higher), prominent cephalic papillae on each lip, and three distinct tooth-like structures projecting into the buccal cavity. The oesophagus in the subgenus has distinct isthmus, lateral alae with double crest and vulva is closed by brown cement in the gravid females. These characters coincide well with subgenus Protenterobius by Inglis (1961) and Inglis \& Dunn 1963).

The type species of this subgenus is L. (Protenterobius) nycticebi (Baylis, 1928), parasitizing Nycticebus coucang (Boddaert) in Malaya and Borneo (Baylis 1928; Inglis 1961; Inglis \& Dunn 1963; Hugot 1999). Only in this species closed vulva by brown cement is recorded by Inglis \& Dunn (1963). We are not agreeing with Inglis and Dunn (1963) that Protenterobius is synonymous with Lemuricola Chabaud et Petter, 1959. We prefer and agree with conclusions by Hugot et al. (1996, p. 147) that "subfamily Enterobiinae includes the following genera or (subgenera): Enterobius Leach, 1853; Colobenterobius Quentin, Betterton et Krishnasamy, 1979; Rodentoxyuris Quentin et Tenora, 1974; Xeroxyuris Hugot, 1995; Lemuricola Chabaud et Petter, 1959; Protenterobius Inglis, 1961; Madoxyuris Chabaud, Brygoo et Petter, 1965; Trypanoxyuris Vevers, 1923; Hapaloxyuris Inglis et Gosgrove, 1965; and Paraoxyuronema Artigas, 1936". Having the well visible isthmus is Protenterobius clearly different from Pongobius (Baruš et al. 2007), which has a special form of oesophagus in the Enterobiinae (isthmus absent and piriform bulb present).

Females of L. (P.) nycticebi differ (Baylis 1928; Inglis \& Dunn 1963) from the L. (P.) pongoi by shorter body (4.5$6.0 \mathrm{~mm})$, and tail $(1.0-1.3)$ length, vulva distance from anterior extremity 1.50-1.75, and bigger eggs (69-87 x 2937). Morphology of the head and mouth is different by a simple structure of teeth in $L$. $(P)$. nycticebi, and by presence of teeth superstructures in $L$. (P.) pongoi. Ratio of body length/total oesophagus length $(8.49$ - 9.29) is different, too.

It is believed that pinworms and their host primates have coevolved (Cameron 1929; Sandosham, 1950; Chabaud et al. 1961; Hugot et al. 1996; Sorci et al. 1997; Hasegawa et al. 2005). L. (P.) nycticebi is specialist parasitizing genus Nycticebus Geoffroy (Lorisidae), his distribution includes: S. Philippines; Assam (India) to Vietnam and Malayan Peninsula; W Indonesia; Yunnan perhaps Kwangsi (China) (Wilson \& Reeder, 2005). Possible divergent co-speciation of ancestral Protenterobius pinworm takes place by hostswitching during the course of evolution of Lorisidae and Ponginae (Hominidae). The family Hominidae, consisting of the great apes and man, contains four genera of hosts that are parasitised by following pinworm species: Enterobius lerouxi, E. vermicularis, E. anthropopitheci E. buckleyi and Pongobius hugoti (see Gedoelst 1916; Sandosham 1950; Hugot 1993, 1999; Hugot et al., 1996; Hasegawa et al., 2005; Nakano et al., 2006; Baruš et al., 2007). Lemuricola (Protenterobius) pongoi differs from all above mentioned species in the generic characters defined by Hugot et al. (1996).

The following nominal pinworm taxa were found in the orangutans (Pongo) also: Enterobius foecundus and E. simiae. The differences of these two species discussed in this paper in relation to E. buckleyi are valid also for $L$. (P.) pongoi. As described Linstow (1879) and McCallum (1921) both species are smaller in body length (6.0-6.5 $\mathrm{mm}) ;$ E. foecundus has longer oesophagus $(1173 \mu \mathrm{m})$ and shorter tail (1083) than L. (P.) pongoi. E. simiae differs in form of oesophagus, having a much shorter isthmus as majority of Enterobius species. We prefer treated both latter pinworms as species inquirendae. The newly described taxon $L$. (P.) pongoi is morphologically and metrically well characterised, and specialised to the host genus Pongo in its native distribution in Sumatra and probably Borneo also (Indonesia).

\section{Acknowledgement}

Authors would like to thank the Indonesian Institute of Sciences (LIPI) and PHKA for the research permit to work in Gunung Leuser National Park. The study was financially supported by the Foundation "UMI - Saving of Pongidae" Parasites and Natural Antiparasitics in Orangutan, by the Research Project of Masaryk University No: MSM0021622416, and by Research Project of the Faculty of Agrobiology, Food and Natural Resources Czech University of Life Sciences i Prague, No: MSM6046070901. The author would also like to thank anonymous reviewers for their helpful comments and Anthony Hurford for editing the English manuscript.

\section{References}

BARUŠ, V., FoitovÁ, I., KoubKovÁ, B., HodovÁ, I., ŠIMKovÁ, A., Nurcahyo, W. (2007): A new nematode, Pongobius hugoti gen. et sp. n. from the orangutan Pongo abelii (Primates: Hominidae). Helminthologia 44: 162 - 169 BAYLIS, H.A. (1928): Some further parasitic worms from Sarawak. Ann. Mag. Nat. Hist. 1: $606-608$

CAMERON, T.W.M. (1929): The species of Enterobius Leach in Primates. J. Helminthol. 7, $161-182$

Chabaud, A. G., Petter, A. J., Golvan, Y. (1961): Les nematodes parasites de lémuriens Malgaches III. Collection récoltée par M. et Mme Francis Petter. Ann. Parasit. Hum. Comp., 36: $113-126$

Collet, J.-Z., GAldikas, B.M.F., SugarJito, J. \& JOJOSUDHARMO, S. (1986): A coprological study of parasitism in orangutan (Pongo pygmaeus) in Indonesia. $J$. Med. Primatol. 5: 121 - 129

FoITovÁ, I. (2002): Parasites in Orangutans (Pongo pygmaeus) with connection to the ecology and ethology factors. Unpublished Ph.D. Thesis, Veterinary and Pharmaceutical University Brno, Czech Republic, 74 pp.

GedoElst, L. (1916): Notes sur la faune parasitaire du Congo Belge. Rev.Zool. Afr. 5: $24-27$

Hasegawa H., IKeda Y., Fujisaki A., Moscovice, L.R., Petrzelkova, K. J., Kaur, T., Huffman, M.A. (2005): 
Morphology of chimpanzee pinworms, Enterobius (Enterobius) anthropopitheci (Gedoelst, 1916) (Nematoda: Oxyuridae), collected from Chimpanzees, Pan troglodytes, on Rubondo Island, Tanzania. J. Parasitol., 91: 1314 - 1317 HugOT, J. P., (1993): Redescription of Enterobius anthropopitheci (Gedoelst, 1916) (Nematoda, Oxyuroidea), a parasite of chimpanzees. Syst. Parasit., 26: $201-207$

HugOT, J. P. (1999): Primates and their pinworm parasites: Cameron hypothesis revisited. Syst. Biol., 48: 523 - 546 Hugot, J. P., Tourte-Schaffer, C. (1985): Etude morphologique des deux oxyures parasites de l'Homme: Enterobius vermicularis et E. gregorii. Ann. Parasit. Hum. Comp., 60: $57-64$

Hugot, J. P., Gardner, S. L., Morand, S. (1996): The Enterobiinae subfam. nov. (Nematoda, Oxyurida) pinworm parasites of primates and rodents. Int. J. Parasitol., 26: 147 $-159$

INGLIS, W. G. (1961): The oxyurids parasites (Nematoda) of primates. P. Zool. Soc. Lond., 136: $103-122$

INGLIS W.G. \& DUNN, F.L. (1963): The occurrence of Lemuricola (Nematoda: Oxyurida) in Malaya: With the description of a new species. Z. Parasitenk. 23: 354 - 359 LINSTOW, O. (1879): Helminthologische Untersuchungen. Wurttemb. natur. Jahreshefte 35: $315-342$

McCallum, G.A. (1921): Studies in Helminthology. Zoopathologica 1: 137 - 284

NaKano, T., OKamoto, M., IKeda, Y. \& Hasegawa, H. (2006): Mitochondrial cytochrome $c$ oxidase subunit 1 gene and nuclear rDNA regions of Enterobius vermicularis parasitic in captive chimpanzees with special reference to its relationship with pinworms in humans. Paras. Res., 100: $51-57$

Mul, I. F., Paembonan, W., Singleton, I., Wich, S. A. AND VAN BOLHUIS, H.G. (2007): Intestinal Parasites of Free-ranging, Semicaptive and Captive Pongo abelii in Sumatra, Indonesia 2007. Int. J.Primatol. 28: 407 - 420

RiJKSEN, H.D. (1978): A field study on Sumatran Orangutans; Ecology, Behavior, and Conservation. Unpublished Ph.D. Thesis, H. Veenman and Zoren, Agriculture University of Wageningen. $420 \mathrm{pp}$.

SAndosham, A. A. (1950): On Enterobius vermicularis (Linnaeus, 1758) and some related species from primates and rodents. J. Helmintol., 24: $171-204$

SkRJABIN, K. I., Schikhobalova, N. P., LAgodovskaya, E. A. (1960): Oxyurids of animals and man. Principles of nematodology, Vol. 8, Publ. House AN SSSR, Moscow, 557 pp. (In Russian)

SorCI G., Morand S., HugOT J.P. (1997): Host parasites coevolution:comparative evidence for covariation of life history traits in primates and oxyurid parasites. Proc R. Soc. London 264: 285 - 289

TENORA, F., BARUŠ, V., WigER, R., RYŠAVÝ, B. (1981): Scanning electron microscopic studies on nematode species of the genera Passalurus, Enterobius and Lemuricola (Oxyurida). Acta U. Agr. Fac. Agron., 29: 327 - 339

WILSON, D. E., REEDER, D. A. (2005): Mammals species of the world. A taxonomic and geographic reference. Vol.1. The Johns Hopkins University Press, Baltimore, 743 pp. 